\title{
Analisis Risiko dan Determinan Kejadian Kecelakaan Kerja di Pabrik Minyak Kelapa Sawit
}

\author{
Willia Novita Eka Rini ${ }^{1, *}$, Budi Aswin ${ }^{2}$,Fajrina Hidayati ${ }^{3}$ \\ I,2,3 Prodi Ilmu Kesehatan Masyarakat, Fakultas Kedokteran dan Ilmu Kesehtan, Universitas Jambi, Jl. Letjend Soeprapto, Kota Jambi, 36361, Indonesia \\ ${ }^{1}$ willia_novita.er@unja.ac.id*; ${ }^{2}$ budiaswin@unja.ac.id; ${ }^{3}$ fajrina.hidayati@unja.ac.id; \\ *corresponding author
}

ARTICLE INFO

Article history

26-08-2021

19-09-2021

05-10-2021

Keywords

Risk analysis

Determinant

Work accident

\begin{abstract}
Safety at work is a series of safety related to machines, work tools, materials and work processes, workplace and environment as well as working methods. Jambi Province is an area that has extensive plantation land, especially for oil palm plantations, based on data from the Central Bureau of Statistics at Provinceof Jambi in 2018. PT. X was experienced the highest incidence of work accidents in the 20172019 range in Jambi Province. This study aims to analyze the risks and determinants of workplace accidents at the palm oil mill at PT. X as an effort to prevent work accidents. This research is analytical research. The population of this study were all workers in the production division of PT. X as many as 96 people consisting of two work shifts and were also used as samples in this study. The data will be analyzed to see the relationship between variables using the ChiSquare test with $(\alpha=0.05)$. There is a relationship between the availability of personal protective equipment (PPE), environmental factors and the use of personal protective equipment (PPE) with the incidence of work accidents in the production division workers of PT. $\mathrm{X}$ while working period, attitude, training and equipment safety are not related in this study.
\end{abstract}

\section{Pendahuluan}

Keselamatan dan kesehatan kerja (K3) merupakan keselamatan yang berhubungan terhadap mesin, alat, bahan dan proses kerja, landasan tempat dan lingkungan kerja, hingga instruksi dalam melakukan pekerjaan. K3 juga mencakup dengan seluruh jenis tempat kerja didarat, udara, permukaan air, bahkan dalam tanah sekalipun, yang menjadi sasaran dalam keselamatan kerja mengenai risiko dan bahaya pekerjaan [1].

Bagi pekerja upaya perlindungan K3 sebagai suatu asset bahkan bagi masyarakat dan negara itu sendiri, karena dalam menjalankan pekerjaannya sehari-hari pekerja dapat dilindungi untuk dapat terhindar bahaya maupun potensi bahaya dari pekerjaan.Dalam mengurangi bahkan dicegahnya hal negatif yang tidak terduga dan tidak diinginkan untuk terjadi merupakan bagian dari lindungan yang diperankan oleh keselamatan kerja [2].

Kecelakaan kerja bukan hal yang terjadi secara kebetulan melainkan terjadi dikarenakan suatu penyebab, yang harus diteliti dan ditemukan agar menjadi landasan dalam melakukan tindakan korektif untuk penyebab tersebut sehingga menjadi upaya preventif lebih lanjutnya.Faktor penyebab kecelakaan melalui toeri domino, yang mengolongkan kecelakaan menjadi dua penyebab yaitu tindakan tidak aman (unsafe act) serta kondisi yang tidak aman (unsafe condition), dan interaksi manusia dan mesin yang tidak aman.Saat ini pendekatan keselamatan kerja bertujuan untuk menghilangkan penyebab kecelakaan kerja di tempat kerja[3].Perilaku tidak aman merupakan penyebab kecelakaan kerja dari aspek faktor manusia yang menyumbangkan angka $80-85 \%$ dari kasus kejadian kecelakaan kerja.Oleh karena itu faktor manusia menjadi aspek yang sangat penting diperbaiki dari segi perilaku yang tidak aman dalam bekerja guna menekan bahkan mencegah kejadian kecelakaan kerja selain dari teknik mekanik, dan keselamatan lingkungan kerja. Berdasarkan data dari 
Organisasi Perburuhan Internasional bahwa dikarenakan kecelakaan akibat kerja di dunia dalam setiap 15 detik terdapat kecelakaan kerja yang dicatat oleh ILO dialami oleh 153 orang pekerja di dunia. 2,78 juta pekerja meninggal setiap tahun karena kecelakaan kerja dan penyakit akibat kerja. Kejadian kecelakaan akibat pekerjaan tercatat lebih dari 380.000 kasus yang mengakibatkan kematian [4].Kejadian kecelakaan kerja di Indonesia berdasarkan data Badan Penyelenggara Jaminan Sosial Ketenagakerjaan (BPJS Ketenagakerjaan) termaksud kategori tinggi, cenderung meningkat tahun 2016 terjadi kecelakaan kerja sebanyak 105.182 mengakibatkan 2.375 pekerja meninggal dunia, tahun 2018 tercatat 147.000 terjadinya kecelakaan kerja,atau 40.273 kasus setiap harinya. Dari jumlah itu, sebanyak 4.678 kasus (3,18 persen) berakibat kecacatan, dan 2.575 (1,75 persen) kasus berakhir dengan kematian, menunjukkan bahwa setiap hari ada 12 orang peserta BPJS Ketenagakerjaan yang mengalami kecacatan, dan tujuh orang peserta meninggal dunia [4].

Provinsi Jambi adalah daerah yang memiliki lahan perkebunan yang luas terutama untuk perkebunan kelapa sawit, berdasarkan data Badan Pusat Statistik Provinsi Jambi pada tahun 2018 luas total perkebunan sawit di Provinsi Jambi mencapai 506.462 ha dan 400.000 ha yang terbagi kepemilikian dari 53 perusahaan dengan jumlah pabrik 57 unit pabrik kelapa sawit. Berdasarkan data kejadian kecelakaan kerja di Provinsi Jambi pada tahun 2017 2019 kejadian kecelakaan kerja pada industri pengolahan kelapa sawit atau PKS (Pabrik Kelapa Sawit) terbeasr terjadi pada PKS X sebanyak 29 kasus kecelakaan [5].

Menurut penelitian Masyudi dan Lizam yang dilakukan pada pekerja pabrik pengolahan kelapa sawit Lembah Bhakti Kabupaten Aceh Singkil bahwa risiko kecelakaan kerja dipengaruhi oleh 3 aspek yaitu regulasi, skil dan lingkungan kerja dengan nilai OR masing-masing yaitu sebesar $(53,1),(4,47)$ dan $(21,26)$ [6]. Menurut hasil penelitian Sitanggang tahun 2017 tentang pengawasan disiplin K3 di kebun kelapa sawit Air Merah Estate mendapat hasil bahwa kurang disiplinnya menggunakan alat pelindung diri (APD) sarung tangan dan visor merupakan kekurangan yang didapat, akan tetapi secara umum kedisiplinan karyawan harian sudah baik [7].

Dikembangkannya manajemen risiko yang berdasarkan pada kajian identifikasi bahaya di tempat kerja dan penilaian risiko merupakan aspek kunci dalam dilaksanakannya keselamatan dan kesehatan kerja serta pencegahan kecelakaan kerja. Sehubungan dengan tingginya kasus kecelakaan kerja di Provinsi Jambi dari tahun ke tahun, dan tingginya kasus kecelakaan kerja yang terjadi dari tahun 2017-2019 di Pabrik Kelapa Sawit X serta kerugian yang dialami oleh perusahaan dan tenaga kerja bahkan keluarga/ ahli waris dari tenaga kerja, maka perlu dilakukan penelitian yang mencari tahu apa risiko dan determinan kejadian kecelakaan kerja tersebut. Adapun tujuan penelitian ini yaitu untuk mengnalisis risiko dan determinan kecelakaan kerja pada pabrik kelapa sawit PT. X sebagai upaya pencegahan kecelakaan kerja dalam mencapai zero accident serta meningkatkan produktivitas kerja.

\section{Metode}

Penelitian ini merupakan studi observasional dengan pendekatan cross-sectional study. Penelitian ini dilaksanakan di PT X Pabrik Kelapa Sawit, yang terletak di Tanjung Jabung Barat, Provinsi Jambi dengan waktu pelaksanaan pada bulan Maret-Oktober 2021.Populasi dalam penelitian ini adalah seluruh pekerja bagian produksi PT.X PMKS sebanyak 96 orang yang terdiri dari dua shift kerja. Pada penelitian ini mengambil total sampel seluruh pekerja bagian produksi yaitu berjumlah 96 orang. Sumber data diperoleh secara langsung melalui wawancara responden dan observasi di lapangan.Dalam penelitian ini juga memerlukan data sekunder yang bersumber dari SDM PT.X, berupa data pekerja, profil dan SOP yang diterapkan di areapabrik.Analisis data dilakukan secara univariat dan bivariat menggunakan uji chi-square pada interval kepercayaan $95 \%$. 


\section{Hasil danDiskusi}

\section{A. DataUnivariat}

PT. X adalah sebuah industri yang bergerak dibidang perkebunan kelapa sawit.Industri ini beralamat di Jl. Lintas WKS, Purwodadi, Tebing Tinggi, Kabupaten Tanjung Jabung Barat, Jambi. PT. X PMKS memiliki tenaga kerja di bagian proses produksi sebanyak 96 orang yang terdiri dari dua shift kerja. Semua pekerja di bagian proses produksi ini sangat berisiko tinggi mengalami kecelakaan kerja mengingat lingkungan kerja perkebunan mempunyai potensi bahaya yang besar. Hasil analisis univariat penelitian adalah sebagai berikut:

Tabel 1. Distribusi Frekuensi Masa Kerja, Sikap tentang K3 dan APD, Pelatihan K3, Ketersediaan APD, Faktor Lingkungan, Keamanan Peralatan, Penggunaan APD dan Kejadian Kecelakaan Kerja.

\begin{tabular}{lcr}
\hline Variabel & Jumlah (n) & Persentase (\%) \\
\hline Masa Kerja & 4 & 4,2 \\
\hline $2-3$ tahun & 42 & 43,8 \\
\hline $4-5$ tahun & 50 & 52,1 \\
\hline$>5$ tahun & $\mathbf{9 6}$ & $\mathbf{1 0 0}$ \\
\hline Total & & \\
\hline Sikap & 21 & 21,9 \\
\hline Kurang & 75 & 78,1 \\
\hline Baik & $\mathbf{9 6}$ & $\mathbf{1 0 0}$ \\
\hline Total & & \\
\hline Pelatihan K3 & 45 & 46,9 \\
\hline Tidak Pernah & 51 & 53,1 \\
\hline Pernah & $\mathbf{9 6}$ & $\mathbf{1 0 0}$ \\
\hline Total & & \\
\hline Ketersediaan APD & 80 & 83,3 \\
\hline Kurang & 16 & 16,7 \\
\hline Baik & $\mathbf{9 6}$ & $\mathbf{1 0 0}$ \\
\hline Total & & \\
\hline Faktor Lingkungan & 51 & 53,1 \\
\hline Berisiko & 45 & 46,9 \\
\hline Kurang Berisiko & $\mathbf{9 6}$ & $\mathbf{1 0 0}$ \\
\hline Total & & \\
\hline Keamanan Peralatan & 56 & 58,3 \\
\hline Kurang & 40 & 41,7 \\
\hline Baik & $\mathbf{9 6}$ & $\mathbf{1 0 0}$ \\
\hline Total & & \\
\hline Pengunaan APD & 45 & 46,9 \\
\hline Kurang Lengkap & 51 & 53,1 \\
\hline Lengkap & $\mathbf{9 6}$ & $\mathbf{1 0 0}$ \\
\hline Total & 52 & 54,2 \\
\hline Kecelakaan Kerja & 44 & $\mathbf{1 0 0}$ \\
\hline Pernah & $\mathbf{9 6}$ & \\
\hline Tidak Pernah & & \\
\hline Total & 0 & \\
\hline Betal & & \\
\hline
\end{tabular}

Berdasarkan tabel 1 diketahui masa kerja pada pekerja di PT. X mayoritas pekerja paling banyak sudah bekerja dengan masa kerja lebih dari 5 tahun yaitu sebanyak 50 pekerja $(52,1 \%)$, sikap pekerja di PT. X tentang K3 dan APD mayoritas pekerja paling banyak 
memiliki sikap baik yaitu sebanyak 75 pekerja $(78,1 \%)$, pelatihan K3 bagi pekerja di PT. X mayoritas pekerja paling banyak pernah mengikuti pelatihan tentang K3 yaitu sebanyak 51 pekerja $(53,1 \%)$ dengan ketersediaan APD bagi pekerja di PT. X kurang baik yaitu sebanyak 80 pekerja $(83,3 \%)$ dan dengan faktor lingkungan bagi pekerja di PT. X berada pada faktor lingkungan yang berisiko yaitu sebanyak 51 pekerja $(53,1 \%)$ dengan keamanan peralatan bagi pekerja yaitu pada keadaan kurang sebanyak 56 pekerja $(58,3 \%)$, penggunaan APD bagi pekerja di PT. X mayoritas pekerja menggunakan APD yang lengkap saat bekerja yaitu sebanyak 51 pekerja $(53,1 \%)$ serta untuk kejadian kecelakaan kerja pada pekerja di PT. X ini mayoritas pekerja pernah mengalami kecelakaan kerja yaitu sebanyak 52 pekerja $(54,2 \%)$.

Tabel 2. Distribusi Frekuensi Jenis Kecelakaan Kerja dan Penyebab Kecelakaan Kerja di PT. X PMKS.

\begin{tabular}{lrr}
\hline Variabel & f & $\mathbf{\%}$ \\
\hline Jenis Kecelakaan Kerja & & \\
\hline Terjatuh & 17 & 32,7 \\
\hline Tertimpa & 6 & 11,5 \\
\hline Tergores & 8 & 15,4 \\
\hline Terbentur & 7 & 13,5 \\
\hline Luka Bakar & 5 & 9,6 \\
\hline Kontak dengan bahan-bahan berbahaya atau radiasi & 3 & 5,8 \\
\hline Terkena arus listrik & 6 & 11,5 \\
\hline Total & $\mathbf{5 2}$ & $\mathbf{1 0 0}$ \\
\hline Penyebab Kecelakaan Kerja & & \\
\hline Alat/Mesin & 18 & 34,6 \\
\hline Tandan Buah Segar (TBS) & 6 & 11,5 \\
\hline Lingkungan Kerja & 17 & 32,7 \\
\hline Human Error & 11 & 21,2 \\
\hline Total & $\mathbf{5 2}$ & $\mathbf{1 0 0}$ \\
\hline
\end{tabular}

Berdasarkan tabel 2 diketahui jenis dari kecelakaan kerja pada pekerja di PT. X. Mayoritas pekerja mengalami kecelakaan kerja terjatuh yaitu sebanyak 17 pekerja $(32,7 \%)$ dan yang paling kecil kecelakaan kerja yang terjadi yaitu dengan jenis kecelakaan kerja kontak dengan bahan-bahan berbahaya atau radiasi sebanyak 3 pekerja $(5,8 \%)$. Kemudian untuk penyebab dari kecelakaan kerja pada pekerja di PT. X mayoritas pekerja mengalami kecelakaan kerja disebabkan karena alat/mesin yang digunakan yaitu sebanyak 18 pekerja $(34,6 \%)$ dan yang paling kecil kecelakaan kerja yang terjadi yaitu disebabkan karena tandan buah segar (TBS) sebanyak 6 pekerja $(11,5 \%)$.

\section{B. Data Bivariat}

Tabel 3. Hasil Uji Chi-Square Variabel Penelitian di PT. X PMKS

\begin{tabular}{|c|c|c|c|c|c|c|c|}
\hline \multirow{3}{*}{ Variabel } & \multicolumn{4}{|c|}{ Kecelakaan Kerja } & & & \multirow{3}{*}{ Nilai $p$} \\
\hline & \multicolumn{2}{|c|}{ Ya, Pernah } & \multicolumn{2}{|c|}{ Tidak Pernah } & \multicolumn{2}{|c|}{ Total } & \\
\hline & $\mathbf{n}$ & $\%$ & $\mathbf{n}$ & $\%$ & $\underset{\%}{\mathbf{n}}$ & & \\
\hline \multicolumn{8}{|l|}{ Masa Kerja } \\
\hline 2-3 tahun & 1 & 25,0 & 3 & 75,0 & 4 & 100 & 0,46 \\
\hline 4-5 tahun & 24 & 57,1 & 18 & 42,9 & 42 & 100 & 7 \\
\hline$>5$ tahun & 27 & 54,0 & 23 & 46,0 & 50 & 100 & \\
\hline \multicolumn{8}{|l|}{ Sikap } \\
\hline Kurang & 9 & 42,9 & 12 & 57,1 & 21 & 100 & 0,353 \\
\hline
\end{tabular}




\begin{tabular}{lccccccc} 
Baik & 43 & 57,3 & 32 & 42,7 & 75 & 100 & \\
\hline Pelatihan & & & & & & & \\
Tidak Pernah & 27 & 60,0 & 18 & 40,0 & 45 & 100 & 0,383 \\
Pernah & 25 & 49,0 & 26 & 51,0 & 51 & 100 & \\
\hline Ketersediaan & & & & & & & \\
APD & & & & & & & \\
Kurang & 48 & 60,0 & 32 & 40,0 & 80 & 100 & 0,022 \\
Baik & 4 & 25,0 & 12 & 75,0 & 16 & 100 & 0,0 \\
\hline
\end{tabular}

\begin{tabular}{llllllll}
\hline Laktor & & & & & & & \\
Berisiko & 3 & & & & 51 & 100 & \\
& 3 & 64,7 & 18 & 35,3 & & & 0,045 \\
Kurang Berisiko & 1 & & & & 45 & 100 & \\
\hline Keamanan & 9 & 42,2 & 26 & 57,8 & & & \\
Peralatan & & & & & & & \\
Kurang & 2 & & & & 56 & 100 & \\
Baik & 9 & 51,8 & 27 & 48,2 & & & 0,729 \\
Penggunaan APD & 2 & & & & 40 & 100 & \\
& 3 & 57,5 & 17 & 42,5 & & & \\
Kurang Lengkap & 3 & & & & & & \\
& 0 & 66,7 & 15 & 33,3 & & & \\
Lengkap & 2 & & & & 51 & 100 & 0,035 \\
\hline
\end{tabular}

Berdasarkan tabel 3 diketahui bahwa dari 4 orang pekerja dengan masa kerja 2-3 tahun di PT. X, ada sebanyak1 orang $(25,0 \%)$ yang pernah mengalami kecelakaan kerja. Dari 42 pekerja dengan masa kerja 4-5 tahun,ada 24 orang $(57,1 \%)$ mengalami kecelakaan kerja dan dari 50 pekerja dengan masa kerja > 5 tahun,ada sebanyak27 orang $(54,0 \%)$ mengalami kecelakaan kerja. Hasil analisis (chi-square test) diperoleh nilai $\mathrm{p}=0,467$ yang lebih besar dari alpha 0,05 artinya tidak ada hubungan masa kerja dengan kecelakaan kerja. Berdasarkan sikap,dari 21 pekerja sikapnya kurang baik tentang K3 dan APD di PT. X,ada 9 orang $(42,9 \%)$ yang pernah mengalami kecelakaan kerja. Dari 75 pekerja sikapnya baik,ada 43 orang $(57,3 \%)$ mengalami kecelakaan kerja. Hasil analisis (chi-square test) diperoleh nilai $\mathrm{p}=0,353$ artinya tidak ada hubungan sikap dengan kecelakaan kerja. Untuk pelatihan dari 45 pekerja yang tidak pernah ikut pelatihan tentang K3,ada 27 orang $(60,0 \%)$ yang pernah mengalami kecelakaan kerja. Kemudian dari 51 pekerja yang pernah ikut pelatihan tentang K3, ada 25 orang $(49,0 \%)$ yang mengalami kecelakaan kerja. Hasil analisis (chisquare test) diperoleh nilai $\mathrm{p}=0,383$ artinya tidak ada hubungan pelatihan dengan kecelakaan kerja.Untuk ketersediaan APDdari 80 pekerja yang bekerja dengan ketersediaan APD yang kurang baik di PT. X,ada 48 orang $(60,0 \%)$ mengalami kecelakaan kerja. Kemudian dari 16 orang pekerja yang bekerja dengan ketersediaan APD yang baik,ada 4 orang $(25,0 \%)$ mengalami kecelakaan kerja. Hasil analisis (chi-square test) diperoleh nilai $\mathrm{p}=0,022$ yang masih lebih kecil dari alpha 0,05 artinya ada hubungan yang signifikan ketersediaan APD dengan kecelakaan kerja di PT. X.Untuk faktor lingkungandari 51 pekerja yang bekerja pada faktor lingkungan yang berisiko ada 33 orang $(64,7 \%)$ yang pernah mengalami kecelakaan kerja. Kemudian dari 45 pekerja yang bekerja pada faktor lingkungan yang kurang berisiko,ada 19 orang $(42,2 \%)$ mengalami kecelakaan kerja. Hasil analisis (chi-square test) diperoleh nilai $\mathrm{p}=0,045$ artinya ada hubungan yang signifikan faktor lingkungan dengan kecelakaan kerja. Untuk keamanan peralatan yang digunakan, dari 
56 pekerja yang bekerja pada keamanan peralatan yang kurang baik,ada 29 orang $(51,8 \%)$ yang pernah mengalami kecelakaan kerja. Kemudian dari 40 pekerja yang bekerja pada keamanan peralatan yang baik,ada 23 orang $(57,5)$ mengalami kecelakaan kerja. Hasil analisis (chi-square test) diperoleh nilai $\mathrm{p}=0,729$ artinya tidak ada hubungan keamanan peralatan dengan kecelakaan kerja. Untuk penggunaan APDdari 45 pekerja yang bekerja dengan menggunakan APD yang kurang lengkap,ada 30 orang $(66,7 \%)$ yang pernah mengalami kecelakaan kerja. Kemudian dari 51 pekerja yang bekerja dengan menggunakan APD yang lengkap,ada 22 orang $(43,1 \%)$ mengalami kecelakaan kerja. Hasil analisis (chisquare test) diperoleh nilai $\mathrm{p}=0,035$ artinya ada hubungan yang signifikan penggunaan APD dengan kecelakaan kerja di PT. X.

\section{Pembahasan}

A. Hubungan Masa Kerja dengan Kecelakaan Kerja di PT. X

Hasil analisis statistik bivariat diperoleh nilai $p>0,05$ artinya tidak ada hubungan masa kerja dengan kecelakaan kerja di PT. X PMKS.Penelitian ini sejalan dengan penelitian Handayani (2010) yang mendapatkan hasil tidak ada hubungan antara masa kerja dengan kecelakaan kerja pada pekerja bagian rustic PT Borneo Melintang Buana Eksport Yogyakarta dengan nilai $p=0,813$ [8]. Hal ini juga didukung oleh penelitian Fauzi (2018) di PT. Pabrik Minyak Kelapa Sawit (PMKS) X di Sumatera Barat yang menyatakan bahwa hasil uji bivariat mendapatkan hasil tidak ada hubungan masa kerja dengan kejadian kecelakaan kerja[9]. Juga sejalan dengan penelitian Martiana dkk (2021) yang mendapatkan hasil tidak terdapat hubungan yang signifikan masa kerja dengan kecelakaan kerja pada industri batubara Kalimantan Selatan [10].

Adanya kaitan searah atau langsung antara masa kerja dengan pengalaman kerja, jika lama masa kerja dari pekerja sudah semakin lama, dapat ditarik pemahaman bahwa pekerja tersebut akan lebih tinggi dan lebih baik juga pengalaman dan jam terbang para pekerja, sehingga para pekerja semakin mengerti dan faham tata cara bekerja lebih baik dan aman sehingga kejadian kecelakaan kerja dapat diminimalkan bahkan tidak menutup kemungkinan kecelakaan kerja tersebut tidak ada sama sekali. Pekerja baru umumnya masih banyak detail pekerjaan yang belum begitu difahami dari aspek pekerjaan secara mendalam. Sebaliknya dengan bertambahnya masa kerja maka semakin meningkat pulalah aspek keselamatan kerja karena diikuti oleh peningkatan pengetahuan dan keterampilan pekerja dalam melaksanakan pekerjaannya [10].

Menurut pengamatan dan asumsi peneliti semakin lama masa kerja maka pekerja akan lebih baik dalam bekerja seperti bekerja sesuai petunjuk, lebih hati-hati, tidak semberono dan lain-lain sehingga kejadian kesalahan pada manusia bisa diminimalisir. Hal ini akan berkorelasi dengan dapat diturunkan angka kejadian kecelakaan kerja.

B. Hubungan Sikap dengan Kecelakaan Kerja di PT. X

Hasil analisis statistik bivariat diperoleh nilai $\mathrm{p}>0,05$ artinya tidak ada hubungan sikap dengan kecelakaan kerja di PT. X.Penelitian ini sejalan dengan penelitian Muharani (2019) di pabrik kelapa sawit adolina PTPN IV Kabupaten Serdang Bedagai yang mendapatkan hasil bahwa tidak terdapat hubungan sikap dengan kejadian kecelakaan kerja dengan nilai $p$ value 0,575[11]. Akan tetapi penelitian ini tidak sejalan dengan penelitian Pangestu (2020) di Pabrik Kelapa Sawit (PKS) PTPN IV Kebun Bah Jambi yang mendapatkan hasil penelitian terdapat hubungan yang signifikan antara sikap dengan tindakan tidak aman $(P$ value 0.000)[12].

Sikap merupakan reaksi atau respons yang masih tertutup dari seseorang terhadap suatu stimulus atau objek.Dari batasan-batasan diatas dapat disimpulkan bahwa manifestasi sikap itu tidak dapat langsung dilihat, tetapi hanya dapat ditafsirkan terlebih dahulu dari perilaku 
yang tertutup.Sikap secara nyata menunjukkan konotasi adanya kesesuaian reaksi terhadap stimulus tertentu yang dalam kehidupan sehari-hari merupakan reaksi yang bersifat emosional terhadap stimulus sosial. Sikap belum merupakan suatu tindakan atau aktivitas, akan tetapi merupakan predisposisi tindakan suatu perilaku. Sikap itu mempunyai tiga komponen pokok yaitu (1) Kepercayaan (keyakinan), ide, dan konsep terhadap suatu objek. (2) Kehidupan emosional atau evaluasi terhadap suatu objek. (3) Kecenderungan untuk bertindak (tend to behave). Ketiga komponen ini secara bersama-sama membentuk sikap yang utuh (total attitude).Dalam penentuan sikap yang utuh ini, pengetahuan, pikiran, keyakinan, dan emosi memegang peranan penting.Sebagai contoh, seorang pekerja mendengar tentang kejadian kasus kecelakaan kerja yang menyebabkan seorang pekerja cacat bahkan meninggal dunia (baik dari segi penyebabnya, akibatnya, pencegahannya, dan sebagainya). Pengetahuan ini akan mendorong seorang pekerja untuk berpikir dan berusaha agar hal tersebut tidak terjadi kepada dirinya. Dalam berpikir ini komponen emosi dan keyakinan ikut bekerja sehingga pekerja tersebut berniat selalu bekerja dengan baik yaitu dengan mematuhi peraturan dari tempat kerja, lebih hati-hati, tidak semberono dan selalu menggunakan APD agar terhindar dari kejadian kecelakaan kerja yang setiap saat dapat terjadi kepada dirinya sendiri dan tenaga kerja lain yang sedang berada pada satu tempat kerja dengannya [13].

Menurut asumsi peneliti sikap tentang K3 dan penggunaan APD sangat penting dalam aspek mencegah kejadian kecelakaan kerja, sedangkan implementasi kerja yang aman merupakan unsur penting karena kecelakaan kerja lebih banyak disebabkan oleh faktor dari pekerja itu sendiri atau yang dikenal dengan kesalahan pada manusia (human error) jika kita bandingkan dengan mesin-mesin atau alat kerja yang digunakan saat bekerja. Sikap yang baik tentang K3 dan penggunaan APD akan menurunkan kejadian kasus kecelakaan kerja. Dari penelitian yang dilakukan dilapangan ditemukan bahwa sikap responden tentang K3 dan penggunaan APD sudah baik, hal tersebut merupakan faktor yang baik untuk mencegah terjadinya kecelakaan kerja pada pekerja.

C. Hubungan Pelatihan dengan Kecelakaan Kerja di PT. X

Hasil analisis statistik bivariat diperoleh nilai $\mathrm{p}>0,05$ artinya tidak ada hubungan pelatihan dengan kecelakaan kerja di PT. X.Penelitian ini tidak sejalan dengan penelitian Rahmayani (2019) yang mendapatkan hasil bahwa terdapat hubungan bermakna antara pelatihan ( $\mathrm{p}$-value $=0,02)$ dengan kecelakaan kerja pada karyawan bagian produksi PT. Tidar kerinci Agung[14]. Penelitian ini juga tidak sejalan dengan penelitian Masyudi dan Lizam (2019) di PT. Perkebunan Pabrik Pengolahan Kelapa Sawit Lembah Bhakti Kabupaten Aceh Singkil yang mendapatkan hasil bahwa ada pengaruh skill terhadap risiko kecelakaan kerja (P. Value $0,021<\alpha=0,05$ ) dan memberikan saran kepada pimpinan untuk meningkatkan skill pekerja dengan cara memberikan penyuluhan serta pelatihan yang berkaitan dengan pekerjaan agar pekerja bisa bekerja dengan profesional dan menurunnya angka kecelakaan kerja [15].

Pelatihan keselamatan dan kesehatan kerja merupakan pelatihan yang diselenggarakan dan diarahkan untuk membekali, meningkatkan, dan mengembangkan kemampuan, produktivitas, dan kesejahteraan tenaga kerja. Kebutuhan pelatihan keselamatan dan kesehatan kerja antara satu perusahaan dengan perusahaan lain berbeda sesuai sifat bahaya, skala kegiatan dan kondisi pekerja. Menurut Soehatman Ramli (2010), pengembangan pelatihan K3 yang baik dan efektif dilakukan melalui Analisa Jabatan atau pekerjaan, Identifikasi pekerjaan atau tugas kritis, Mengkaji data-data kecelakaan, Survei kebutuhan pelatihan, Analisa kebutuhan pelatihan, Menentukan sasaran dan target pelatihan, Mengembangkan objektif pembelajaran, Melaksanakan pelatihan, Melakukan evaluasi dan Melakukan perbaikan [3]. 
Menurut asumsi peneliti pelatihan keselamatan dan kesehatan kerja sangat penting karena begitu banyak kecelakaan kerja terjadi dikarenakan para pekerja belum biasa bekerja secara selamat. Penyebab kejadian kecelakaan kerja mayoritas disebabkan faktor manusia sebagai contoh ketidaktahuan tentang bahaya atau cara mencegahnya. Oleh karena itu dengan adanya pelatihan tentang K3 diharapkan dapat meningkatkan kemampuan terkait permasalahan $\mathrm{K} 3$ dalam bekerja menjadi lebih baik.

D. Hubungan Ketersediaan APD dengan Kecelakaan Kerja di PT. X

Hasil analisis statistik bivariat diperoleh nilai $\mathrm{p}<0,05$ artinya ada hubungan yang signifikan ketersediaan APD dengan kecelakaan kerja. Penelitian ini sejalan dengan penelitian Lestari (2016) yang mendapatkan hasil bahwa berdasarkan hasil uji statistik Chi Square didapat p-value 0,001 yang disimpulkan ada hubungan yang signifikan antara ketersediaan APD terhadap kejadian kecelakaan terjadi PT. Johan Kabupaten Kampar Tahun 2016 dengan nilai OR (Odds Ratio) $=14,25[16]$. Pengusaha wajib menyediakan APD bagi pekerja/buruh ditempat kerja dengan Standar Nasional Inndonesia (SNI) atau Standar yang berlaku dan APD di berikan secara cuma-cuma [17].

Menurut asumsi peneliti ketersediaan APD yang kurang baik bagi pekerja menyebabkan terjadinya kecelakaan kerja yang dialami oleh pekerja seperti terpeleset, terjatuh, terpapar bahan-bahan atau material, tertimpa benda berat bahkan terkena sengatan listrik. Selain kesalahan pihak perusahaan, tidak tersedianya APD yang baik juga disebabkan oleh kelalaian yang disebabkan oleh pekerja seperti lupa membawa APD saat bekerja, tidak mau menggunakan APD dengan alasan rasa tidak nyaman saat bekerja, bahkan ada yang beranggapan bahwa APD dapat mengganggu proses bekerja serta kurangnya pengawasan yang dilakukan oleh pihak perusahaan.

E. Hubungan Faktor Lingkungan dengan Kecelakaan Kerja di PT. X

Hasil analisis statistik bivariat diperoleh nilai $\mathrm{p}<0,05$ artinya ada hubungan yang signifikan faktor lingkungan dengan kecelakaan kerja di PT. X. Penelitian ini sejalan dengan penelitian Muharani dan Dameria (2019) yang mendapatkan hasil bahwa terdapat hubungan lingkungan kerja dengan kejadian kecelakaan kerja dengan $p$-value 0,000 pada pekerja di bagian produksi pabrik kelapa sawit Adolina PTPN IV Kabupaten Serdang Bedagai[11]. Penelitian ini juga sejalan dengan penelitian Masyudi dan Lizam (2019) di PT. Perkebunan Pabrik Pengolahan Kelapa Sawit Lembah Bhakti Kabupaten Aceh Singkil yang mendapatkan hasil bahwa ada pengaruh lingkungan kerja terhadap risiko kecelakaan kerja (P. Value $0,000<\alpha=0,05)$ [15]. Juga sejalan dengan penelitian Aprillia dkk (2017) yang mendapatkan hasil adanya hubungan antara lingkungan sosial kerja terhadap perilaku tidak aman dengan nilai probabilitas $0,001[18]$.

Lingkungan kerja memiliki pengaruh yang signifikan terhadap kecelakaan kerja, walaupun pekerja telah berhati-hati, namun apabila lingkungannya tidak mendukung (tidak aman) maka kecelakaan dapat terjadi, begitu sebaliknya.Pedoman kerja diperlukan agar pekerja melakukan setiap pekerjaannya sesuai dengan prinsip-prinsip keselamatan kerja.Lingkungan kerja yang baik pasti mendukung pekerja dalam melakukan setiap pekerjaannya. Lingkungan merupakan tempat yang digunakan oleh pekerja untuk melakukan pekerjaannya akan secara langsung dapat menjadi faktor penyebab dari terjadinya kecelakaan kerja bagi pekerja[19].

Menurut asumsi peneliti menemukan bahwa masih terdapat lingkungan kerja yang belum baik seperti lantai licin akibat dari minyak sawit atau adanya genangan air sehingga hal tersebut membuat perkerja mengalami kecelakaan kerja seperti terpeleset/terjatuh, tertimpa benda atau material, tertumbuk atau terkena benda-benda. 
F. Hubungan Faktor Keamanan Peralatan dengan Kecelakaan Kerja di PT. X

Hasil analisis statistik bivariat diperoleh nilai $\mathrm{p}>0,05$ artinya tidak ada hubungan faktor keamanan peralatan dengan kecelakaan kerja. Penelitian ini tidak sejalan dengan penelitian Afriani (2020) yang mendapatkan hasil bahwa 17 pemanen yang mengalami kecelakaan kerja terkena duri, terkena kampak, terkena gancu, dan tertimpa pelepah yang mengakibatkan kerugian waktu, hasil, serta luka ringan. Adapun faktor penyebab kecelakaan kerja adalah pada tindakan tidak aman (penggunaan alat kerja) terdapat kendala yaitu kurang memperhatikan menggunakan alat kerja dengan baik, dan faktor kondisi tidak aman (peralatan kerja) terdapat kendala pada galah egrek mengalami patah. Dapat disimpulkan bahwa dari penelitian penggunaan alat kerja dengan tidak konsentrasi, terburu buru dan terdapat kendala pada peralatan kerja yang mengalami rusak sehingga dapat mengakibatkan kelalaian dalam bekerja[20]. Juga sejalan dengan penelitian Taofiq (2019) yang mendapatkan hasil bahwa kejadian kecelakaan kerja di Pabrik Pengolahan Kelapa Sawit PT. X Kabupaten Kubu Raya disebabkan oleh alat kerja sebesar 52,39\% [21].

Faktor peralatan kerja dapat menjadi pemicu terjadinya kecelakaan kerja.Salah satu factor peralatan dapat ditinjau dari kondisi mesin.Dengan mesin dan alat mekanik, produksi dan produktivitas dapat ditingkatkan.Selain itu, beban kerja faktor manusia dikurangi dan pekerjaan dapat lebih berarti.Apabila keadaan mesin rusak, dan tidak segera diantisipasi dapat menyebabkan terjadinya kecelakaan kerja.Ketersediaan alat pengaman mesin.Mesin dan alat mekanik terutama diamankan dengan pemasangan pagar dan perlengkapan pengamanan mesin atau disebut pengaman mesin.Dapat ditekannya angka kecelakaan kerja oleh mesin adalah akibat dari secara meluasnya dipergunakan pengaman tersebut.Letak mesin Terdapat hubungan yang timbal balik antara manusia dan mesin.Fungsi manusia dalam hubungan manusia mesin dalam rangkaian produksi adalah sebagai pengendali jalannya mesin tersebut.Mesin dan alat diatur sehingga cukup aman dan efisien untuk melakukan pekerjaan dan mudah.Termasuk juga dalam tata letak dalam menempatkan posisi mesin. Semakin jauh letak mesin dengan pekerja, maka potensi bahaya yang menyebabkan kecelakaan akan lebih kecil. Sehingga dapat mengurangi jumlah kecelakaan yang mungkin terjadi [22]. Menurut asumsi peneliti menemukan bahwa masih terdapat peralatan kerja yang berumur sudah lama tetapi masih tetap digunakan dan terdapat juga beberapa alat kerja yang perlu pemeliharaan agar tetap dapat bisa digunakan di masa mendatang.

G. Hubungan Penggunaan APD dengan Kecelakaan Kerja di PT. X

Hasil analisis statistik bivariat diperoleh nilai $\mathrm{p}<0,05$ artinya ada hubungan yang signifikan penggunaan APD dengan kecelakaan kerja. Penelitian ini sejalan dengan penelitian Muharani dan Dameria (2019) yang mendapatkan hasil bahwa terdapat hubungan tindakan penggunaan APD dengan kejadian kecelakaan kerja dengan p-value 0,002 pada pekerja di bagian produksi pabrik kelapa sawit Adolina PTPN IV Kabupaten Serdang Bedagai[11]. Penelitian ini juga sejalan dengan penelitian Sihombing (2017) bahwa didapatkan hasil ada hubungan yang bermakna (signifikan) antara pemakaian alat pelindung diri dengan kecelakaan kerja dengan nilai $p=0,037$ pada pekerja kelapa sawit di PT. Socfindo Kebun Bangun Bandar Kabupaten Serdang Bedagai [23].

Tindakan responden yang kurang baik yang tercermin dalam penggunaan APD yang kurang lengkap dapat dipengaruhi oleh banyak faktor.Faktor internal (berupa respons) dan faktor ekstenal (berupa stimulus) sangat berpengaruh terhadap tindakan penggunaan APD.Faktor internal merupakan faktor yang berada dalam diri individu sedangkan faktor eksternal merupakan faktor yang berada diluar individu (faktor lingkungan, baik fisik maupun nonfisik dalam bentuk sosial, budaya, ekonomi dan politik).Penggunaan APD 
merupakan salah satu upaya pencegahan kecelakaan kerja. Penggunaan APD yang baik dan benar akan melindungi pekerja dari bahaya yang ada di lingkungan kerja baik dari bahaya unsafe action maupun unsafe condition. Pada saat penelitian ditemukan bahwa mayoritas pekerja belum menggunakan APD secara lengkap saat melakukan pekerjaan.Pekerja merasa tidak nyaman menggunakan APD secara lengkap karena sudah terbiasa tidak menggunakan APD pada saat melakukan pekerjaan [13].

Menurut asumsi peneliti penggunaan alat pelindung diri merupakan alternatif terakhir sebagai salah satu upaya pencegahan kecelakaan kerja, akan tetapi juga dapat sebagai alternatif pertama jika kondisi bahaya kerja sangat menghawatirkan sehingga membuat pemakaian APD menjadi wajib ssebelum bekerja. Penggunaan alat pelindung diri di tempat kerja disesuaikan dengan pajanan bahaya yang dihadapi di area kerja.Untuk itu pemakain alat pelindung diri sangat penting nilainya sebagai pencegahan terjadinya kecelakaan kerja. Suasana kerja dengan kenyamanan tempat kerja dan kenyamanan fasilitas seperti halnya kondisi APD akan berkorelasi dengan peningkatan prestasi kerja dari setiap tenaga kerja, sehingga dengan demikian diharapkan setiap fasilitas atau perlengkapan kerja yang menimbulkan kenyamanan dalam pemakaianannya akan dapat digunakan oleh pekerja secara optimal. Tindakan penggunaan alat pelindung diri sangat penting karena dapat mencegah timbulnya kecelakaan akibat suatu pekerjaan.

\section{Kesimpulan}

Kesimpulan yang didapat adalah pekerja paling banyak pernah mengalami kecelakaan kerja.Jenis kecelakaan kerja yang paling banyak terjadi yaitu terjatuh dan mayoritas pekerja yang mengalami kecelakaan kerja disebabkan karena alat/mesin yang digunakan.Tidak ada hubungan masa kerja, sikap tentang K3 dan APD, pelatihan dan keamanan peralatan dengan kejadiaan kecelakaan kerja.Ada hubungan ketersediaan APD, faktor lingkungan dan penggunaan APD dengan kejadiaan kecelakaan kerja pada pekerja bagianproduksi PT. X.

\section{Ucapan TerimaKasih}

Terima kasih kepada pimpinan PT. X PMKS beserta staff yang telah banyak membantu penelitian ini mulai dari survey awal sampai dengan selesainya penelitian ini.

\section{Referensi}

[1] Suma'mur, P.K., Higiene Perusahaan dan Kesehatan Kerja (HIPERKES). 2 ed. Jakarta: Sagung Seto:407-411. 2020.

[2] Kharismasari, Cynthia Nur and, Tarwaka PGDip., Sc., M.Erg. Hubungan Pengetahuan Dan Perilaku K3 Dengan Budaya K3 Bagi Perawat Di Rumah Sakit Widodo Ngawi. Skripsi thesis, Universitas MuhammadyahSurakarta. 2018.

[3] Soehatman, R., Sistem Manajemen Keselamatan \& Kesehatan Kerja OHSAS 18001. Jakarta: DianRakyat. 2010.

[4] BPJS Ketenagakerjaan. Jumlah Kecelakaan Kerja di Indonesia Masih Tinggi. [Online]http://www.bpjsketenagakerjaan.go.id/berita/5769/Jumlah-kecelakaan-kerjadiIndonesiamasih-tinggi.html.[diakses 1 November 2019]. 2019.

[5] BPJS Ketenagakerjaan Provinsi Jambi. Data Klaim BPJS Ketenagakerjaan. Jambi.

[6] Masyudi dan Lizam, T. C., 2019. Analisis Risiko Kecelakaan Kerja Pada Pekerja Pabrik Pengolahan Kelapa Sawit Lembah Bhakti Kabupaten Aceh Singkil. 2019.

[7] Sitanggang dan Aprilliaty., W. Analisis Pengawasan Disiplin Keselamatan Dan Kesehatan Kerja (K3) Karyawan Kebun Kelapa Sawit Air Merah Estate, KetapangKalimantan Barat. 2017.

[8] Handayani, E.E., Wibowo, T.A., Suryani, D. Hubungan Antara Penggunaan Alat Pelindung Diri, Umur dan Masa Kerja Dengan Kecelakaan Kerja pada Pekerja Bagian 
Rustic di PT Borneo Melintang Buana Eksport Yogyakarta. Yogyakarta. 2010.

[9] Fauzi, A., dan Kusnanto, H. Faktor-Faktor yang Berhubungan dengan Kejadian Kecelakaan Kerja di PT Pabrik Minyak Kelapa Sawit (PMKS) X di Sumatera Barat. 2018.

[10] Martiana, T., Arahnca, dan Zikri. Hubungan antara Umur, Masa Kerja, dan Tingkat Pendidikan dengan Kecelakaan Kerja di Industri Batubara Kalimantan Selatan. Indian Journal of Forensic and Toxicology. 2021.

[11] Muharani, R., dan Dameria. Faktor yang Berhubungan dengan Kejadian Kecelakaan Kerja Pada Pekerja di Bagian Produksi Pabrik Kelapa Sawit Adolina PTPN IV Kabupaten Serdang Bedagai. Medan. 2019.

[12] Pangestu, A. Hubungan Karakteristik, Pengetahuan dan Sikap dengan Tindakan Tidak Aman Pekerja Pabrik Kelapa Sawit (PKS) PTPN IV Kebun Bah Jambi. 2020.

[13] Pakpahan dkk. Promosi Kesehatan dan Perilaku Kesehatan. Yayasan Kita Menulis. 2021.

[14] Rahmayani, M. Hubungan Pelaksanaan Program K3 Dengan Terjadinya Kecelakaan Kerja Pada Karyawan Bagian Produksi Pabrik Kelapa Sawit PT. Tidar Kerinci Agung, Dharmasraya Tahun 2018. 2019.

[15] Masyudi dan Lizam, T. C., Analisis Risiko Kecelakaan Kerja Pada Pekerja Pabrik Pengolahan Kelapa Sawit Lembah Bhakti Kabupaten Aceh Singkil. 2019.

[16] Lestari, R. R. Faktor-Faktor Peningkatan Terjadinya Kecelakaan Kerja Di Bagian Produksi di PT. Johan Kabupaten Kampar. 2016.

[17] Peraturan Menteri Tenaga Kerja dan Transmigrasi. Republik Indonesia. Nomor PER.08/MEN/VII/2010. Tentang. Alat Pelindung Diri. 2010.

[18] Aprillia, I. Hubungan Budaya Keselamatan dan Kesehatan Kerja (K3) terhadap Perilaku Tidak Aman pada Pekerja Bagian Panen PT. X Kabupaten Mempawah. 2017.

[19] Sari SC, Hamid D, Utami HN. Keselamatan dan Kesehatan Kerja (Studi pada Karyawan Pabrik Gondorukem dan Terpentin Sukun Perum Perhutani Kesatuan Bisnis Mandiri Industri Gondorukem dan Terpentin II , Ponorogo). 2016.

[20] Afriani, D. Analisis Faktor Penyebab Kecelakaan Kerja Pada Pemanen Kelapa Sawit di PT. Perkebunan Nusantara VII Unit Betung. 2020.

[21] Taofiq, F. I.. Analisis Risiko dan Kejadian Kecelakaan Kerja di Pabrik Pengolahan Kelapa Sawit (Studi di PT. X Kabupaten Kubu Raya). Pontianak. 2019.

[22] Safetyshoe. 3 Faktor Penyebab Kecelakaan Kerja (Three Main Factor Theory). https://www.safetyshoe.com/3-faktor-penyebab-kecelakaan-kerja-k3-mencakup-5-mfaktor-manusia/). 2021.

[23] Sihombing, O., Hubungan Pemakaian Alat Pelindung Diri Dengan Kecelakaan Kerja Pada Pekerja Kelapa Sawit di PT. Socfindo Kebun Bangun Bandar Kabupaten Serdang Bedagai. Medan. 2017. 